\title{
Иванова Н.В., Джинджолия Р.С. \\ О некоторых новшествах в арбитражном законодательстве и повышения роли юристов с высшим юридическим образованием или имеющих ученую степень по специальности юриспруденция
}

МИРЭА-Российский технологический университет

(Россия, Москва)

doi: $10.18411 / l j-02-2021-207$

idsp: ljournal-02-2021-207

Аннотация

В статье рассматриваются нововведения в арбитражном законодательстве. Автор обращает внимание на те изменения и дополнения, которые наиболее четко защищают права и интересы сторон арбитражного процесса, судьи как субъекта разрешения арбитражного спора и статуса лица, участвующего в деле в качестве представителя, каким может быть только юрист с высшим юридическим образованием или имеющий ученую степень по юриспруденции.

Ключевые слова: арбитражный процесс, стороны арбитражного процесса, лицо, с высшим юридическим образованием, арбитражное представительство.

\section{Abstract}

The article considers innovations in arbitration law. The author draws attention to the changes and additions that most clearly protect the rights and interests of the parties to the arbitration process, the judge as the subject of the resolution of the arbitration dispute and the status of the person involved in the case as a representative, which can only be a lawyer with a higher legal education or having a law degree.

Keywords: arbitration process, parties to the arbitration process, person with higher legal education, arbitration representation.

Как и любая отрасль законодательства, нормативно-правовые акты арбитражного судопроизводства постоянно совершенствуются, их основные положения приводятся в соответствие с изменившимися обстоятельствами.

По состоянию на 2019-2020 гг. соответствующие актуальные изменения коснулись следующих обстоятельств, которые, как нам представляется, существенно усовершенствовали нормы арбитражного процесса и практику их применения. Так, по решению Пленума Верховного Суда РФ с 1 октября 2019 г. начали свою деятельность кассационные и апелляционные суды общей юрисдикции. В это же время вступил в силу Федеральный Закон от 28.11.2018 г. N 451-Ф3 «О внесении изменений в отдельные законодательные акты Российской Федерации» [2], который содержит большую часть новаций арбитражного процессуального кодекса (АПК РФ) [1].

Выделим и охарактеризуем наиболее важные, с нашей точки зрения, новшества.

Институт судебного представительства. Законом внесены актуальные изменения в части представительства в арбитражных судах. Теперь представлять интересы доверителя (юридического лица либо индивидуального предпринимателя) может только лицо, имеющее высшее юридическое образование либо ученую степень по юридической специальности. Подтверждением является документ (диплом) о высшем юридическом образовании или ученой степени по юридическим наукам (ч. 3 ст. 59 АПК РФ).

Как нам представляется, это своевременное новшество, оно справедливо повышает статус практикующих юристов (до этого нововведения в суде могли представительствовать лица и без надлежащего образования, не обладающие должной 
квалификацией юриста). Конечно, повышение требований к квалификации представителей в арбитражном судопроизводстве может повлечь за собой рост стоимости юридических услуг, представляемых квалифицированными юристами, однако же это сделает и соответствующие услуги более квалифицированными, что повышает статус юридического образования, повысится требование к юридическим образовательным организациям [4, с.61]. Это сделает также профессию юриста еще более востребованным и привлекательным, а его услуги более результативными.

Расширение прав сторон арбитражного прочесса при заключении мирового соглашения. Согласно появившимся новшествам, условия мирового соглашения не могут быть изменены судом, суд также не вправе исключать из условий мирового соглашения отдельные положения, за исключением отдельных условий, противоречащие по судебному усмотрению закону или нарушающие права и законные интересы других лиц (п. 8 ст. 141 АПК РФ). Однако после утверждения мирового соглашения соответствующим определением, оно (определение) нельзя будет оспорить в кассационном порядке.

Введена также новая процедура под названием «судебное примирение» в соответствии со ст. 138.5 АПК РФ и институт судебных примирителей.

Итак, расширение прав сторон при заключении мирового соглашения, на наш взгляд, можно назвать положительным и своевременным в арбитражном процессе. Можно выделить следующие положительные моменты:

- мировое соглашение повлечет за собой позитивное последствие в предпринимательских спорах, на практике покажет себя в качестве наиболее востребованного механизма разрешения арбитражных дел;

- позитивным является ограничение вмешательства суда во взаимоприемлемые договоренности сторон (раньше на практике это часто вызывало недовольство и ущемление интересов одной из сторон судом);

- стороны могут прийти к любому компромиссу, не опасаясь, что судья внесет изменения в их соглашение;

- суд при утверждении мирового соглашения будет следить лишь за тем, чтобы в результате не были ущемлены интересы или возложены какиелибо обязательства на третьих лиц, не участвующих в споре;

- дела, по которым будут заключены мировые соглашения, станут рассматриваться быстрее и эффективнее;

- грамотно проведенные переговоры между сторонами и корректно составленное мировое соглашение юристами, участвующими в деле в качестве представителей, будут гарантировать утверждение соглашения судом и беспрепятственное его исполнение [5, с.128].

Расширение полномочий судей. Новшества коснулись, того что судья в соответствии с подп. 8 п.2 ст. 153 и п. 4.1 ст. 154 АПК РФ наделен правом определять продолжительность выступления стороны в суде, при наличии соответствующих основании (например, участник нарушает последовательность выступлений, дважды не исполняет требования председательствующего, допускает грубые выражения или оскорбительные высказывания либо призывает к осуществлению действий, преследуемых в соответствии с законом).

Данное новшество, несомненно, повышает статус судьи как участника арбитражного процесса, выполняющего функцию разрешения спора, что, на наш взгляд, в то же время немногим ограничивает право стороны в изложении своей правовой позиции по предмету спора (например, на практике в настоящее время возникает не мало казусом, когда судья, используя данное право, не слушает стороны или его представителя) [6, с.43]. 
Однако, как нам представляется, эту ситуацию может смягчить квалифицированный юрист - представитель стороны, который используя свои профессиональные знания, наиболее четко сможет изложить позицию стороны и добиться желаемого для стороны результата, что еще раз подтверждает правильность законодателя, принявшего закон о том, что только юрист с высшим юридическим образованием может представлять интерес доверителя (юридического лица либо индивидуального предпринимателя).

Отметим еще несколько новшеств, согласно которым в исходе арбитражного спора участие квалифицированного юриста окажется еще более результативны.

Ужесточение требований к процессуальным документам и процедуре их подачи и получения. Лицо, подающее исковое заявление, должно иметь полномочия на эти действия, подтвержденные доверенностью, прилагаемой к материалам. В соответствии с подп. 6 п. 1 ст. 129 АПК РФ, подача искового заявления неуполномоченным лицом является самостоятельным основанием его возвращения. Такой же порядок применяется и при подаче апелляционной (кассационной) жалобы. Апелляционная жалоба в арбитражном процессе будет возвращена, если нет подписи или не подтверждены соответствующие полномочия. Причем если стороной процесса является гражданин, то в процессуальных документах, включая исковое заявление должны быть указаны в соответствии с п. 2 ст. 125 АПК РФ:

- для гражданина - фамилия, имя, отчество (при наличии) и место жительства, а также дата и место рождения, место работы (если они известны) и один из идентификаторов (страховой номер индивидуального лицевого счета, идентификационный номер налогоплательщика, серия и номер документа, удостоверяющего личность, основной государственный регистрационный номер индивидуального предпринимателя, серия и номер водительского удостоверения, серия и номер свидетельства о регистрации транспортного средства);

- для организации - наименование и адрес, а также идентификационный номер налогоплательщика и основной государственный регистрационный номер, если они известны [7, с. 108].

Исполнительный лист выдается только по ходатайству взыскателя (п. 3 ст. 319 АПК РФ).

Критерии и основания отмены судебных актов в суде кассаџионной инстанции. Основаниями для пересмотра в порядке кассационного производства решений и постановлений судов нижестоящей инстанции являются существенные нарушения норм материального права и (или) норм процессуального права, которые повлияли на исход дела, без устранения которых невозможны восстановление и защита нарушенных прав, свобод, законных интересов в сфере предпринимательской и иной экономической деятельности, а также защита охраняемых законом публичных интересов (п. 3 ст. 288.2; п. 1 ст. 291.1 АПК РФ).

Также уточнена компетенция судов кассационной инстанции в части отмены судебных актов, в их задачу теперь не входит установление фактических обстоятельств дела. Отмена решений осуществляется только в случае обнаружения существенных нарушений норм материального и процессуального права, если эти нарушения могли повлиять на решение суда.

При этом роль профессионального юриста, ведущего дело, и здесь существенна, так как подавая кассационную жалобу, нужно будет ему (юристу) больше описывать процессуальные нарушения, а не фактические обстоятельства дела. А противной стороне нужно будет избегать даже мелких нарушений, чтобы не дать повода для удовлетворения кассационной жалобы. Все это требует высокой 
юридической квалификации лица, у которого в обязательном порядке должно быть высшее юридическое образование и который участвует в деле.

Понятие подведомственности суда. В соответствии со ст. 27, 256.2 и ч.1 ст. 33 АПК РФ понятие «подведомственность» заменено понятием «компетенция суда», в связи с чем изменены и некоторые процессуальные правила (например, если суд установит, что дело должен рассмотреть суд другой компетенции, он не прекращает производство, а передает материалы по компетенции).

С 1 сентября 2019 года законом введена обязательная аудиозапись протокола судебного заседания (отсутствие аудиозаписи судебного заседания будет самостоятельным основанием для отмены судебных актов первой и апелляционной инстанций (ст. 288 АПК РФ).

Теперь рассмотрим и проанализируем и другие новшества в арбитражном процессе.

Так, в соответствии с п. 2 ст. 25 АПК РФ отвод судьи находится в компетенции председателя судебного состава, заместителя или председателя суда. С сентября 2019 года вопрос о своем отводе судьи начали решать сами. Надо отметить, что на практике отводы судей бывают не более, чем в $10 \%$ случаев при подаче соответствующих заявлений [6, с. 88]. Новая норма сведёт этот процент к минимуму, так как ранее заявление вышестоящему судье всё же могло повлиять на судью, который отклонился, например, от соблюдения норм арбитражного процессуального законодательства $[6,38]$.

В соответствии с п.1 ст. 266 АПК РФ апелляционные жалобы на определения арбитражных судов теперь рассматриваются судьей единолично, кроме определений по делам о банкротстве. Как справедливо отмечается в юридической литературе, это новшество увеличит значимость решения суда первой инстанции для положительного результата судебного разбирательства. Подготовка и ведение дела в первой инстанции становится гораздо более ответственным [7, с.27].

В соответствии с изменениями и дополнениями в АПК РФ увеличены судебные штрафы, которые судья может налагать на граждан и должностных лиц (ст. 119 АПК РФ), также увеличена цена иска по делам, рассматриваемым в порядке упрощенного производства (ст. 227 АПК РФ. При этом не подлежат рассмотрению в порядке упрощенного производства дела об оспаривании решений и действий (бездействия) должностного лица службы судебных приставов, дела, относящиеся к подсудности суда по интеллектуальным правам в качестве суда первой инстанции, дела о несостоятельности (банкротстве), дела, связанные с обращением взыскания на средства бюджетов бюджетной системы Российской Федерации (подп. 4 п. 1 ст. 227 АПК РФ).

Мотивированное решение по делам, рассматриваемым в порядке упрощенного производства, арбитражный суд будет обязан подготовить не только в случае подачи соответствующего заявления, но также в случае подачи апелляционной жалобы (п. 2 ст. 229 АПК РФ).

Срок рассмотрения арбитражного дела увеличен в два раза и сокращается срок предъявления требования о возмещении судебных издержек (ст. 112 АПК), что немногим разгрузить работу судей.

Также увеличен срок для подачи замечаний на протокол (п. 7 ст. 155 АПК РФ), что, с нашей точки зрения, является положительным моментом. Так как, отсчёт данного срока начинается с момента подписания протокола судьей, сторонам по делу требуется время для его получения, им намного легче будет уложиться в срок.

Таким образом, подводя итог всему изложенному можно сделать вывод: изменения и дополнения в арбитражное законодательство можно рассматривать как прогрессивное в законодательстве, учитывающем интересы сторон и суда, разрешающего дела, также, что самое главное, увеличивающем значимость 
практикующего юриста, представляющего интересы стороны в арбитражном процессе.

\title{
$* * *$
}

1. Арбитражный процессуальный кодекс Российской Федерации от 24.07.2002 N 95-Ф3 (ред. от 08.12.2020) /КонсультантПлюс

2. Федеральный закон от 28.11.2018 N 451-Ф3 (ред. от 17.10.2019) «О внесении изменений в отдельные законодательные акты Российской Федерации» (ред. от 08.12.2020)

3. Бармина О.Н. Арбитражный процесс. Учебное пособие. М.: Проспект, 2020. 160 c.

4. Бармина О.Н. Учебное пособие по арбитражному процессу. Конспект лекций. М.: Проспект, 2020. $88 \mathrm{c}$.

5. Жуйков В.М. Комментарий практики рассмотрения экономических споров (судебно-арбитражной практики) /А.А. Аюрова; Е.Е. Баглаева; О.А. Беляева и др.; под ред. В.М. Жуйкова. М.: ИЗиСП, КОНТРАКТ, 2019. Вып. 26. 248c.

6. Комментарий практики рассмотрения экономических споров (судебно-арбитражной практики) /Г.Г. Астахов, О.А. Беляева, Е.Ю. Борзило и др.; отв. ред. В.Ф. Яковлев. М.: ИЗиСП, КОНТРАКТ, 2019. Вып. 25. 240 с.

7. Особенности арбитражного производства: учебно-практическое пособие / О.В. Абознова, Ю.В. Аверков, Н.Г. Беляева и др.; под ред. И.В. Решетниковой. Москва: Юстиция, 2019. Серия «Арбитраж». 324 с.

\section{Кафиатулина А.В. ${ }^{1}$, Криницын Н.O. ${ }^{2}$ \\ Прокурорский надзор за соблюдением жилищных прав граждан}

\author{
${ }^{1}$ Ивановский филиал РАНхИГС \\ ${ }^{2}$ Ивановский государственный университет \\ (Россия, Иваново)
}

doi: $10.18411 / l j-02-2021-208$

idsp: ljournal-02-2021-208

\section{Аннотация}

В ходе осуществления прокурорского надзора за соблюдением жилищных прав граждан на практике возникает множество проблем, например, когда при переселении граждан из аварийного жилья реально жилищные условия у переселяемых граждан не улучшаются. Органы власти предлагают жилые помещения такой же площади, часто в домах, не сильно отличающихся по техническому состоянию от снесенных, при этом оставляя людей в статусе нуждающихся в улучшении жилищных условий. Сложившаяся практика не решает жилищный вопрос граждан. Поэтому, жилищное законодательство требует корректировки.

Ключевые слова: прокуратура, прокурорский надзор, жилищные права, выселение.

\section{Abstract}

In the course of the prosecutor's supervision over the observance of the housing rights of citizens, many problems arise in practice, for example, when the real housing conditions of the resettled citizens do not improve during the relocation of citizens from emergency housing. The authorities offer residential premises of the same size, often in houses that do not differ much in technical condition from the demolished ones, while leaving people with the status of needing to improve their housing conditions. Thus, there is a change of "awl for soap", without actually solving the housing issue. Therefore, the housing legislation needs to be adjusted.

Keywords: prosecutor's office, housing, eviction.

Обеспечение соблюдения прав граждан в жилищно-коммунальной сфере является одним из приоритетных направлений деятельности органов прокуратуры. 